\title{
Assessment of yield and water use efficiency of durum wheat as affected by irrigation practices and soil properties in the irrigated area of oued rmel in Tunisia
}

\author{
Sami Bhouri Khila ${ }^{1}$, Boutheina Douh ${ }^{1}$, Amel Mguidiche ${ }^{1}$, Mohsen Mansour ${ }^{2}$, \\ Abdelhamid Boujelben ${ }^{1}$ \\ ${ }^{\text {I }}$ Higher Agronomic Institute of Chott Mariem. BP 47, 4042 Chott Mariem, Sousse. Tunisia) \\ ${ }^{2}$ (Regional Research Center in Horticulture and Organic Farming, BP.57, 4042, Chott Mariem, Sousse, \\ Tunisia)
}

\begin{abstract}
This work aims to study the impact of total available soil water in the root zone (TAW) on the relation between irrigation regime and water use efficiency of a durum wheat (Triticum durum Desf. Var. Karim.) cultivar in the pedoclimatic conditions of the irrigated area of Oued Rmel in Tunisia. After calibration, STICS model was used to simulate effects of two irrigation scenarios on water use efficiency of durum wheat over a 20-year period with regard to farmers irrigation practices in the study area. To carry out the study, three types of soil in the Oued rmel irrigation scheme were chosen on the basis of their TAW. Two scenarios of irrigation scheduling were designed through the STICS model: (i) irrigation was scheduled when $50 \%$ of the TAW was depleted (I50); (ii) irrigation was scheduled when 25\% of the TAW was depleted (I25). Results showed that lowest values of grain yield were obtained in soil having low TAW as a consequence of a frequent water stress occurring during the reproductive stage of wheat. The highest values of WUE, as determined at grain and biomass basis (WUE $E_{g}$ and $W U E_{\text {bio }}$ indexes), were obtained when irrigation was scheduled at $25 \%$ of the TAW depletion. In I5O and I25 scenarios, highest WUEg, averaging respectively 2.25 and $2.23 \mathrm{~kg} \mathrm{~m}^{-3}$ was obtained in soil having high TAW. As noticed for WUEg, highest values of WUE bio were registred in soil having high TAW.
\end{abstract}

Keywords: crop model, durum wheat, irrigation, water use efficiency,

\section{INTRODUCTION}

In Tunisia, cereal yields are subject to significant fluctuation, given the interannual variability of rainfall, in addition to seasonal moisture deficits that may prevail, even during a wet year [1]. Obtaining high yields of cereals require, in addition to chemical treatments, irrigation and use of mineral fertilizers [2], [3], [4] [5]. However, in Tunisia, as in countries with semi-arid climate, shortage of water is ever one of the main limitations for agricultural development [6]. Research on better use of available rainfall and the interactions between effects of soil, and field management on cereal production is required. Scientists should provide technical information to guide farmers and policy makers in making decisions that optimize the dual objectives of high crop yield and low environmental degradation [7]. Thus, Cereals occupy a place in the primary agricultural research programs in Tunisia. This place is particularly important as the country wants to achieve a stable grain production in particular for durum wheat [8]. Faced with demographic change, the fragility of the agricultural sector and the scarcity of water resources, it is clear that the challenge is to maximize the crop water use efficiency [9]. Water use efficiency is a useful indicator for quantifying the impact of irrigation scheduling decisions with regard to water management [10]. It has been shown that the variability observed in determining water use efficiency, may be largely attributed to the water regime applied [11]; [5]; [12]; [3];[9]. However, [12] showed that, when providing operational suggestions to optimize irrigation management, the impact of climate and of soil properties should attentively be considered since they can provide a certain amount of settlements. In the last years, crop growth models have been widely used as an important tool to investigate the responses of crops and varieties in different pedoclimatic conditions [13]. Crop growth models can be used as a tool for increasing water productivity with appropriate irrigation management [14]. Simulation models, driven by daily climatic data, can be used to predict the impact of long-term climate variability on the probability of success of a range of crop, water and soil management strategies thus providing an opportunity of 'accelerated learning' compared with the traditional multi-location, multi-seasonal and multi-factorial field trials [15]. The potentials and limits of dynamic simulation models as predictive tools have been discussed [16];[17]; [18], concluding that crop modeling could provide unique advantages in several situations [19]. In this work, STICS model [20] was calibrated with the objective of analyzing the combined effects of irrigation scheduling and the soil total available water in the root zone (TAW) on yield and water use efficiency of durum wheat in the pedoclimatic conditions of the irrigated area of Oued Rmel in Tunisia. 


\subsection{The study area}

\section{MATERIALS AND METHODS}

The analysis has been achieved on the Oued Rmel irrigation scheme $\left(35^{\circ} 55^{\prime} \mathrm{N}-10^{\circ} 25^{\prime}\right.$ E) located in Northeastern part of Tunisia. The scheme covers an irrigated area of about 4770 ha. The Oued rmel scheme is supplied by the Oued Rmel dam, located in a dominant position with respect to the served area. Its reservoir has a total capacity of $70 \mathrm{Mm} 3$. The overall amount of water withdrawn from the Oued Rmel reservoir for irrigation purpose varies from $3 \mathrm{Mm}^{3}$ to $100 \mathrm{Mm}^{3}$ sincce annual distribution of precipitation is very irregular. Water is distributed to farmers by means of large-scale pressurized distribution system, operated by a local Water Users Association. The irrigation delivery service usually starts from mid October and lasts up to the end of June. Freqeuncy and amount of water delivered depends on the dam water level. The dominant crops are fruit trees and cereals, mainly durum wheat. Wheat is generally sown between mid November and mid December, depending on climatic conditions and the start of the rainfall season

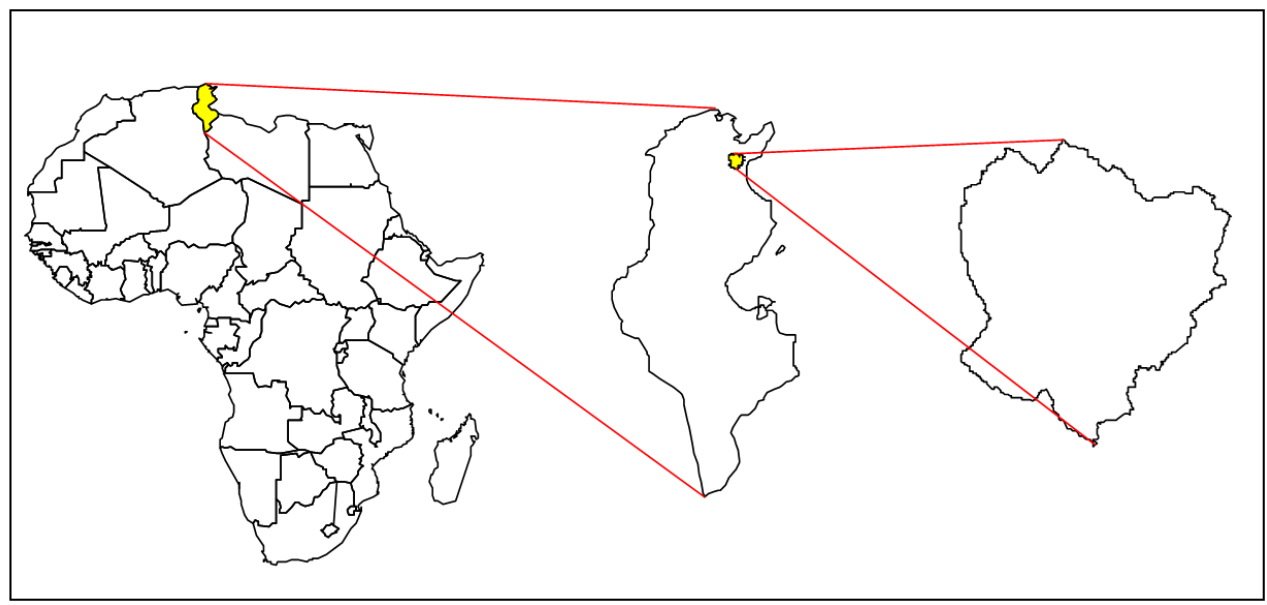

Figure 1. Location of the study area

In the study area, the climate is typically Mediterranean with hot-dry summers and mild-rainy winters. According to long term weather data (1986-2006), maximum monthly temperatures range between 16 and $32{ }^{\circ} \mathrm{C}$ and minimum monthly temperature vary from 7 to $21^{\circ} \mathrm{C}$. Mean relative humidity vary from $65 \%$ to $74 \%$. Monthly rainfall ranges between 2 and $48 \mathrm{~mm}$

Table 1. Long term mean (1986- 2006) meteorological data in the study area (source: National Meteorological Institute of Tunisia)

\begin{tabular}{|c|c|c|c|c|}
\hline & \multicolumn{2}{|c|}{ Average of temperature $\left({ }^{\circ} \mathrm{C}\right)$} & \multirow{2}{*}{$\begin{array}{l}\text { Mean relative } \\
\text { humidity }(\%)\end{array}$} & \multirow{2}{*}{$\begin{array}{c}\text { wind speed } \\
\left(\mathrm{m}^{-1} \mathrm{~s}^{-1}\right)\end{array}$} \\
\hline & Tmax & Tmin & & \\
\hline January & 15.69 & 7.24 & 76.16 & 1.49 \\
\hline February & 16.32 & 7.04 & 72.98 & 1.72 \\
\hline March & 18.28 & 8.79 & 71.52 & 1.82 \\
\hline April & 20.3 & 10.49 & 71.13 & 1.7 \\
\hline May & 23.64 & 13.92 & 69.67 & 1.78 \\
\hline June & 28.49 & 17.44 & 65.25 & 1.66 \\
\hline July & 31.15 & 20.05 & 65.6 & 1.68 \\
\hline August & 32.08 & 21.25 & 67.51 & 1.61 \\
\hline September & 28.84 & 19.87 & 73.21 & 1.5 \\
\hline Otober & 25.38 & 16.85 & 74.73 & 1.37 \\
\hline November & 20.27 & 12.01 & 73.93 & 1.49 \\
\hline December & 17.03 & 8.36 & 75.32 & 1.41 \\
\hline
\end{tabular}




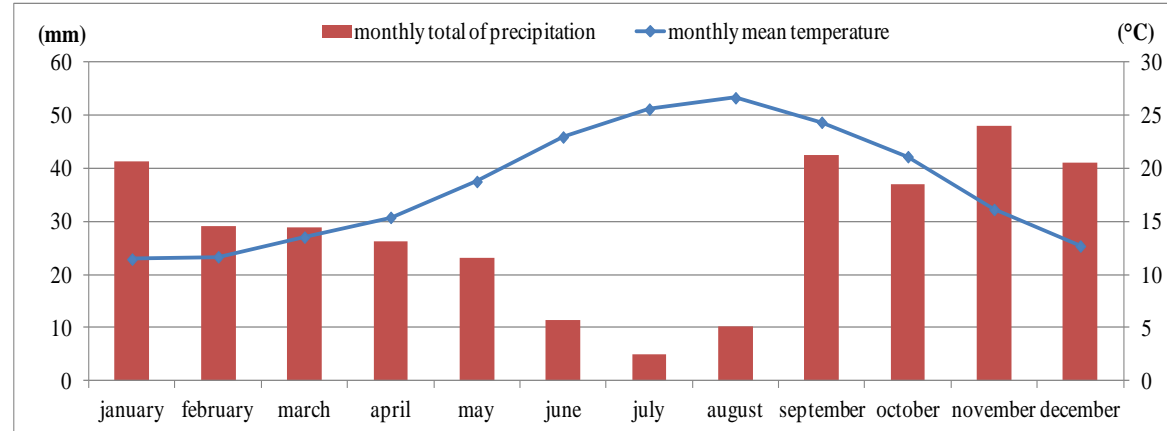

Figure 2. Long term mean monthly rainfall distribution and mean air temperature in the study area. To carry out the study, three types of soil (S1, S2 and S3) in the Oued rmel irrigation scheme were chosen on the basis of their available soil water in the root zone (TAW) and their significant representativeness in the region. According to [21], these soils show contrasting characteristics in terms of total available soil water in the root zone. Tables 2, 3 and 4 summarize the main characteristics of these soils.

Table 2: main characteristics of the soil S1

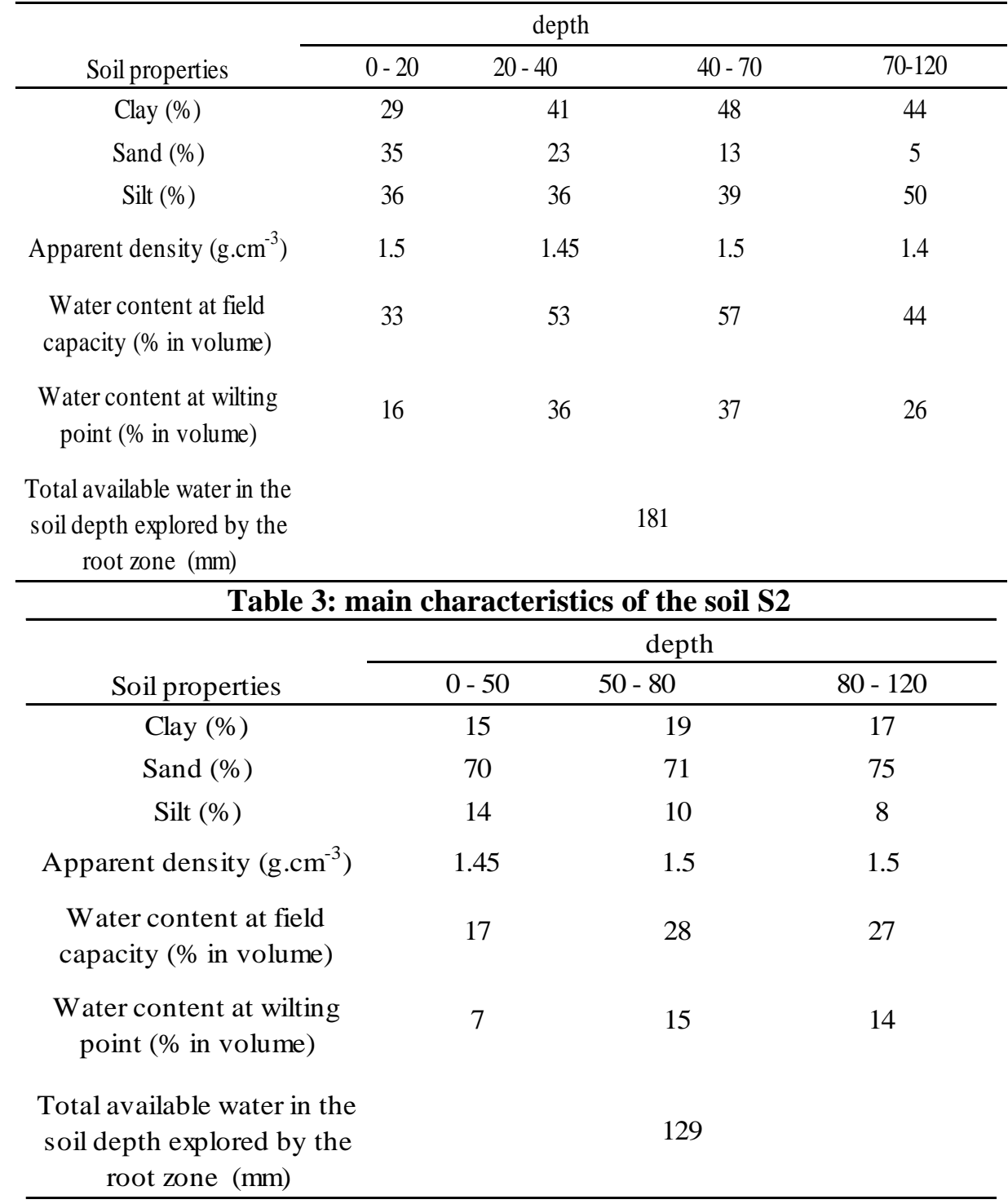


Table 4: main characteristics of the soil S3

\begin{tabular}{cccc}
\hline & \multicolumn{3}{c}{ depth } \\
\cline { 2 - 4 } Soil properties & $0-50$ & $50-70$ & $70-120$ \\
\hline Clay (\%) & 16 & 14 & 16 \\
Sand (\%) & 80 & 70 & 78 \\
Silt (\%) & 4 & 16 & 6 \\
Apparent density (g.cm $\left.{ }^{-3}\right)$ & 1.35 & 1.4 & 1.35 \\
Water content at field & 10 & 16 & 4 \\
capacity (\% in volume) & & 7 & \\
$\begin{array}{c}\text { Water content at wilting } \\
\text { point (\% in volume) }\end{array}$ & 4 & & \\
Total available water in the & & 72.8 & \\
soil depth explored by the \\
root zone (mm)
\end{tabular}

The TAW describes the available water storage in the soil which may be exploited by the root system. It is defined as the difference between the soil water contents at field capacity and at wilting point, multiplied by the depth of the root system [22]. The water content at field capacity and at wilting point depends on the specific physical properties of the soil, especially its texture. The soil depth which may be explored by the root system is a specific characteristic of each cultivated species [12]. As for durum wheat, [23] proved that the soil depth explored by the root system is not deeper than $1 \mathrm{~m}$.

\subsection{Model description}

STICS (Simulateur Multidisciplinaire des Cultures Standards), has been developed since 1996 at INRA (France) in collaboration with other research or professional institutes [24]. From the characterization of climate, soil, species and crop management, it computes output variables related to yield in terms of quantity and quality, environment in terms of drainage and nitrate leaching, and to soil characteristics evolution under cropping system [25]. STICS is widely used in a lot of agro-environmental contexts [26]; [27]; [28]. It was retained in this study as it showed a wider scope, serving at the same time for research and management objectives. In addition, some tests carried out in the South of France showed that the STICS model correctly simulated winter wheat crop behaviour under water shortage conditions [29]. The model is composed of a number of modules (see figure 2). There are modules that deal with: i) the physiology of the aboveground plant parts, ii) the interactions between the crop management and the soil-crop system, iii) the micro-climate, and iv) the interactions between soil and subsurface plant parts [30]

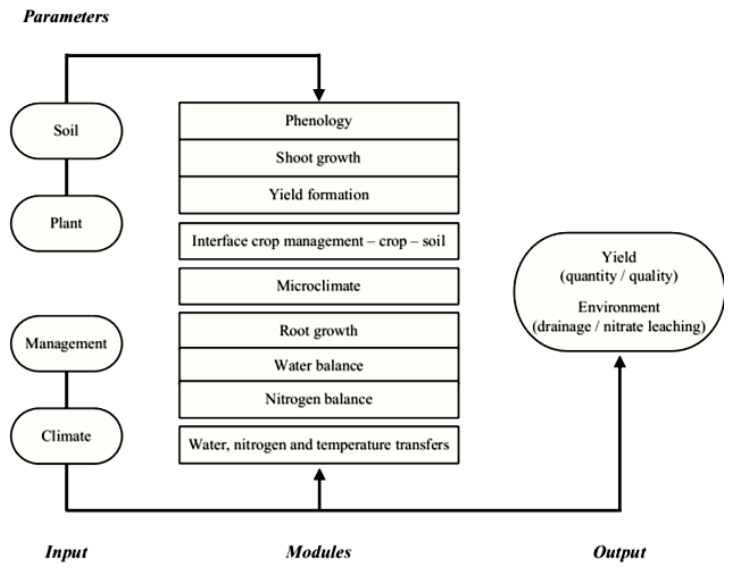

Figure 3. Overview of the model system and its components [30]

The model requires information about initial and permanent conditions of soil, plant functioning and crop management and is driven by daily climatic data (solar radiation, minimum and maximum temperature, precipitation and reference evapotranspiration) [30]. STICS simulates the crop growth from sowing to harvest, focusing on the evolution of the LAI at a few selected vegetative stages [25]. Crop growth is driven by the plant carbon accumulation [31]: solar radiation intercepted by the foliage and then transformed into aboveground biomass that is directed to the harvested organs during the final phase of the crop cycle. Daily accumulation of aboveground biomass is a function of the intercepted radiation according to a parabolic law involving the maximal radiation use efficiency (RUE) [24]. A more detailed description of the model, its structure and interlinkages is given in [24], [20]. 


\subsection{Model evaluation}

Model evaluation is an essential step in the modelling process because it indicates if the implementation of the calculations involved reproduces the conceptual model of the system to be simulated (model reliability) and the level of accuracy of the model in reproducing the actual system (model usefulness) [32]. Model evaluation includes any action in which the goodness of a mathematical model is established [33], [34]. The topic of model evaluation has long attracted considerable debate amongst members of the scientific community. Much debate has stressed over the meaning of terms such as "testing", "validation", "verification" and "calibration" as part of the process collectively referred to as "evaluation" [35]. Model calibration could be defined as the estimation of some model parameters by fitting the overall model to field data [36]. Parameter estimation for complex process models used in agronomy or the environmental sciences is important, because it is a major determinant of model predictive power, and difficult, because the models and associated data are complex [36].

A database from 8 experiments conducted on a durum wheat (Triticum durum Desf. Var. Karim.) cultivar was used to evaluate and calibrate the model. As shown in tables 5 and 6 , the data sets for these experiments are characterized by variability of location, soil characteristics and crop management. Since the cultivation practices affect the development, growth and grain yield. The model will be evaluated in various conditions,

Table 5. Some management practices carried out during the experiments used for model validation

\begin{tabular}{ccccccc}
\hline Experiment & Location & Sowing date & $\begin{array}{c}\text { Seed } \\
\text { number.m } \mathrm{m}^{-2}\end{array}$ & Harvest date & $\begin{array}{c}\text { Irrigation } \\
(\mathrm{mm})\end{array}$ & $\begin{array}{c}\text { Fertilization } \\
\left(\mathrm{kg} \cdot \mathrm{ha}^{-1}\right)\end{array}$ \\
\hline calibration & & & & & & \\
1 & Nabeul & $10 / 12 / 1991$ & 500 & $26 / 06 / 1992$ & 230 & none \\
2 & Nabeul & $10 / 12 / 1991$ & 500 & $11 / 06 / 1992$ & none & 120 \\
3 & Nabeul & $10 / 12 / 1991$ & 500 & $24 / 06 / 1992$ & none & none \\
4 & Nabeul & $10 / 12 / 1991$ & 500 & $26 / 06 / 1992$ & 230 & 120 \\
validation & & & & & & \\
5 & Bizerte & $15 / 11 / 1998$ & 350 & $15 / 05 / 1999$ & 83 & 500 \\
6 & Tunis & $17 / 11 / 1998$ & 350 & $12 / 05 / 1999$ & 25 & 450 \\
7 & Tunis & $16 / 11 / 1995$ & 350 & $15 / 05 / 1996$ & 100 & none \\
8 & Tunis & $24 / 11 / 1995$ & 350 & $19 / 05 / 1996$ & 100 & none \\
\hline
\end{tabular}

Experiments were carried out in Tunis $\left(36^{\circ} 48^{\prime} \mathrm{N}-10^{\circ} 11^{\prime} \mathrm{E}\right)$ during $1995-1996$ and $1998-1999$ growing seasons,

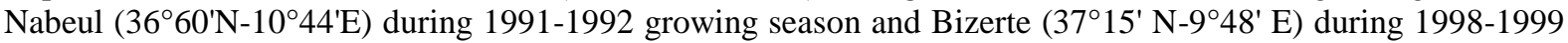
growing season. The campaigns of measures during the trials have concerned phenological stages, above-ground biomass, final grain yield and soil water content. Experiments from 1 to 4 have been described by [37]. Experiments 5 and 6 have been described in detail by [38]; while experiments 7 and 8 have been described by [39].

Table 6. Mean characteristics of the soils observed at the experimental sites

\begin{tabular}{lccccccc}
\hline experiment & $\begin{array}{c}\text { soil depth } \\
(\mathrm{cm})\end{array}$ & Clay (\%) & Sand (\%) & Silt (\%) & $\begin{array}{c}\text { Apparent } \\
\text { density } \\
\left(\mathrm{g} . \mathrm{cm}^{-3}\right)\end{array}$ & $\begin{array}{c}\text { Water } \\
\text { content at } \\
\text { field } \\
\text { capacity (\% } \\
\text { in volume })\end{array}$ & $\begin{array}{c}\text { Water } \\
\text { wilting point } \\
\text { (\% in } \\
\text { volume })\end{array}$ \\
\hline $\begin{array}{l}\text { experiments } \\
\text { from 1 to 4 }\end{array}$ & 100 & 8 & 76 & 16 & 1.57 & 32 & 11 \\
experiment 5 & 100 & 31 & 35 & 34 & 1.47 & 36 & 25 \\
experiment 6 & 100 & 41 & 32 & 27 & 1.65 & 34 & 22 \\
experiment 7 & 120 & 30 & 20 & 50 & 1.55 & 33 & 20 \\
experiment 8 & 120 & 55 & 5 & 40 & 1.56 & 47 & 32 \\
\hline
\end{tabular}

STICS was run after preparing the input data files consist of meteorological data, irrigation, plant, and soil information for the eight experiments. Model evaluation was conducted using root mean square of error (RMSE), model efficiency (ME), coefficient of determination $\left(\mathrm{R}^{2}\right)$ and mean Biais $(\mathrm{MB})$ criterions obtained as follows: 


$$
\begin{gathered}
R^{2}=\frac{\left[\sum_{i=1}^{n}\left(Y_{i}-\bar{Y}\right)\left(X_{i}-\bar{X}\right)\right]^{2}}{\left[\sum_{i=1}^{n}\left(Y_{i}-\overline{Y)^{2}}\right]\left[\sum_{i=1}^{n}\left(X_{i}-\bar{X}\right)^{2}\right]\right.} \\
R M S E=\sqrt{\frac{1}{n} \sum_{i=1}^{n}\left(Y_{i}-X_{i}\right)^{2}} \\
R R M S E=\frac{R M S E}{\bar{X}} \\
M E=1-\frac{\sum_{i=1}^{N}\left(X_{i}-Y_{i}\right)^{2}}{\sum_{I=1}^{N}\left(X_{i}-\bar{X}\right)^{2}} \\
M B=\frac{\sum_{I=1}^{N} Y_{i}-\sum_{I=1}^{N} Y_{S}}{\sum_{I=1}^{N} Y_{i}}
\end{gathered}
$$

Where $\mathrm{Yi}$ is the predicted variable, $\mathrm{Xi}$ is the observed value, $\overline{\mathrm{Y}}$ is the predicted mean, $\overline{\mathrm{X}}$ is the measured mean, and $\mathrm{n}$ is the number of observation.

$\mathrm{R}^{2}$ represents the proportion of variation in the sample data that is explained by the regression model. It is only an estimate of the proportion of variation in the population that is explained by the regression model [40]. Practitioners would be advised to avoid selecting a model based solely on the criterion of observing a high $\mathrm{R}^{2}$ value. This is especially true when many terms are included in a model to fit a relatively small number of observations [40]. The RMSE indicates the error of prediction of the model by giving more weight to high errors. A low value of RMSE means a good prediction ability of the model. Also, ME ranges from negative infinity to positive 1 ; the closer to 1 , the more robust the model. RMSE provides quantitative estimates of the deviation of modelled outcomes from measurements [41]. [42], likewise, indicated RMSE as stable statistics. The modelling efficiency statistic [43], interpreted as the proportion of variation explained by the model, has been extensively used in plant and hydrology models [44], [45], and can certainly be used in biological and ecological models [41]. Moreover, visual comparison of modelled and measured data, and experience-based judgement on the part of the modeller have been deemed important by researchers for assessing model validity and applicability in decision making [46].

After calibration the model was used to assess the farmer's irrigation in a durum wheat cultivar (Triticum durum Desf. Var. Karim.) compared to rainfed system in the study area. In fact, farmers generally irrigate winter wheat one time at sowing. Usually, the amount of irrigation water applied is equal to $40 \mathrm{~mm}$. Fertilizer (ammonium nitrate 33.5\%) is generally applied at a rate of $200 \mathrm{~kg}$.ha-1. Simulations were performed year by year during the 1986-2006 period at the three identified soils, under experimental neutrality (same sowing date and fertilisation). Precipitation was obtained from recorded measurements on the test site itself while other climate data were documented using records from the nearby "Oued Souhil" weather station $(20 \mathrm{~km}$ away).

Collected data in this study were analyzed and examined statistically using analysis of variance (ANOVA) from the Statistical Analysis System (SPSS 17.0 for Windows) (SPSS inc., Chicago, IL, USA). Means were compared by the SNK Test at the 5\% level of significance

\subsection{Water use efficiency}

The term water use efficiency originates in the economic concept of productivity. Productivity measures the same amount of any given resource that must be expended to produce one unit of any goods or service [47]. The WUE terms are presented as non-dimensional values and they do not represent an output/input ratio of only one entity. In fact, they describe the processes in which water is consumed and/or used to produce new entities (e.g. biomass, yield, etc) [48]. Some authors adopt it to express the water productivity of the irrigation water [49]. Excluding experimental errors related to the determination of yield and ET, the variability in determining WUE (Fig. 4) can have mainly three sources: (1) agro-techniques: water and fertilizer applied to crops and analysed in terms of quantity and quality; (2) plant: differences between species, variety effects, phenological stage sensitivity to water constraints; (3) environment: soil and climate [50].

Water use efficiency (WUE) has been the most widely used parameter to describe irrigation effectiveness in terms of crop yield [49]. Two approaches can be considered to determine water use efficiency: i) the ecophysiological approach, based on the analysis at a given instant of the relationship between photosynthesis and transpiration per leaf unit area, at the leaf scale, crop canopy scale, and territorial scale [52], ii) the agronomical approach based on water consumption and yield concept [53]. The time scale considered is the whole vegetative cycle. Eco-physiological and agronomic approaches are really linked, as recently showed by [54].

Since the study of de Wit (1958), different expressions (WUE, crop water productivity) have been proposed and discussed [55], [56];; [57]; [58]; [59]; [9]; [60]; [54]. In general, WUE can be written as follows [50]:

$$
\text { WUE }=\frac{\text { yield }}{\text { water consumption }}
$$


Yield in equation can be indicated by two parameters: (1) global dry matter yield; (2) marketable crop yield. In durum wheat, the marketable crop yield is a criterion more interesting than dry matter. In fact, for species like durum wheat, yield can vary significantly as a result of genetic improvement [61].

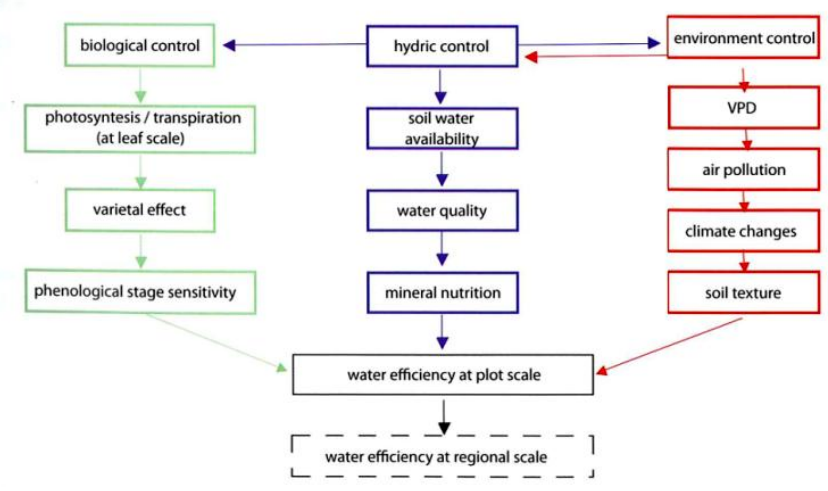

Figure 4. Schematic overview of the parameters involved in the determination of WUE [51]

Furthermore, to analyse crop water use efficiency in relation with the irrigation management and soil properties, two indexes have been proposed:

$$
\begin{aligned}
& \mathrm{WUE}_{\text {bio }}=\frac{\mathrm{Y}}{\mathrm{ET}}(5) \\
& \mathrm{WUEg}=\frac{\mathrm{B}}{\mathrm{ET}}(6)
\end{aligned}
$$

Where WUEbio = crop water use efficiency at biomass basis (kg.m-3), WUEg= crop water use efficiency at grain basis (kg.m-3), Y = grain yield (kg.ha-1), B= dry matter at harvest (kg.ha-1), ET= seasonal evapotranspiration (m3.ha-1)

\subsection{Model calibration}

\section{Results And Discussion}

Model calibration was conducted by changing the crop parameters and based on the best matching between simulated and measured dry biomass and grain yield. The initial cultivar parameters were chosen based on default values for the durum wheat cultivar named "Acalou" included in the model. The total number of crop parameters is very large in a crop simulation model such as STICS model [26]. Thus, in some parameters, the recommended default values by model guidelines were considered. Calibration concerned parameters defining the course of development between two successive stages (stlevamf, stamflax, stlevdrp, stdrpmat) and the harvest index growth rate (vitircarbt). The calibrated parameters values were determined by testing a range of values as suggested by [62]. The selected values were those which minimized the difference between simulations and measurements. Through repeated simulation runs and output comparison of simulated versus observed yield and biomass, a set of four conservative parameters was obtained which seemed most appropriate and gave satisfactory results of situations simulated (table 7).

\begin{tabular}{|c|c|c|c|c|}
\hline parameter & definition & $\begin{array}{c}\text { Evaluation } \\
\text { range }\end{array}$ & Initial Value & $\begin{array}{l}\text { Value after } \\
\text { calibration }\end{array}$ \\
\hline Stlevamf & $\begin{array}{l}\text { The sum of development units between } \\
\text { the day of seedling emergence and the } \\
\text { day of maximum acceleration in the } \\
\text { growth of LAI (degree-days) }\end{array}$ & $210-450$ & 228 & 218 \\
\hline Stamflax & $\begin{array}{l}\text { sum of development units between the } \\
\text { day of maximum acceleration in the } \\
\text { growth of LAl and the first day of } \\
\text { maximum LAl (degree-days) }\end{array}$ & $300-474$ & 207 & 207 \\
\hline Stlevdrp & $\begin{array}{l}\text { sum of development units between the } \\
\text { day of seedling emergence and the first } \\
\text { day of seed filling (degree-days) }\end{array}$ & $600-1300$ & 695 & 650 \\
\hline stdrpmat & $\begin{array}{l}\text { sum of development units between the } \\
\text { first day of seed filling and the first day of } \\
\text { seed filling and physiological maturity } \\
\text { (dearee-days) }\end{array}$ & $520-700$ & 527 & 572 \\
\hline
\end{tabular}

Table 7. Adjusted model parameters

STICS performed with satisfactory precision in terms of wheat yield and biomass. This is confirmed by the statistics displayed in Table 8. Values of RRMSE, ME, $\mathrm{R}^{2}$ and ND indicate that the calibrated model performed 
with satisfactory precision in terms of wheat yield and biomass. According to [29] and [28], values of MB and $\mathrm{ME}$ indicate that the calibration is satisfactory. Furthermore, $\mathrm{R}^{2}$ was higher than the generally acceptable value of 0.5 [62]; [63].

Table 8 Statistical indices for evaluating the performance of STICS model in predicting grain yield and

\begin{tabular}{lcc}
\multicolumn{3}{c}{ dry biomass after calibration } \\
\hline & grain yield & dry biomass \\
\hline RMSE & 1.28 & 1.84 \\
RRMSE (\%) & 24 & 20 \\
$|\mathrm{MB}|$ & 0.02 & 0.13 \\
$\mathrm{ME}$ & 0.47 & 0.76 \\
$\mathrm{R}^{2}$ & 0.52 & 0.86 \\
\hline
\end{tabular}

\subsection{Model validation}

\subsubsection{Grain yield and dry biomass}

Generally, there was a close agreement between the measured and simulated dry biomass. These qualitative findings are confirmed by the statistics (figure 5). The coefficient of determination is larger than 0.9, ME is 0.9 and RMSE is 0.66 t.ha $^{-1}$ representing $20 \%$ of the average observed value of dry biomass. Furthermore, the simulation is considered good as the normalized RMSE is greater than $10 \%$ and less than $20 \%[64]$.

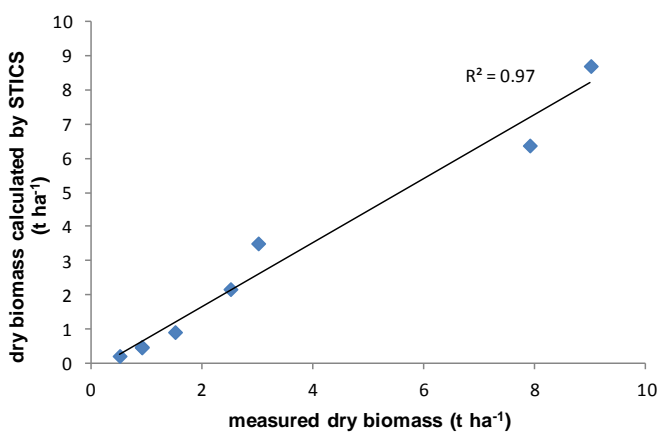

Figure 5. Comparison of simulated and measured dry matter using validation data set

Figure 6 shows the comparison of the simulated and observed grain yield. RMSE was 0.65 t.ha $^{-1}$ which represented $11 \%$ of the average observed measured yield and MB was 0.08. According to [64] and [29], these values indicate a reasonable agreement between measured and simulated yield

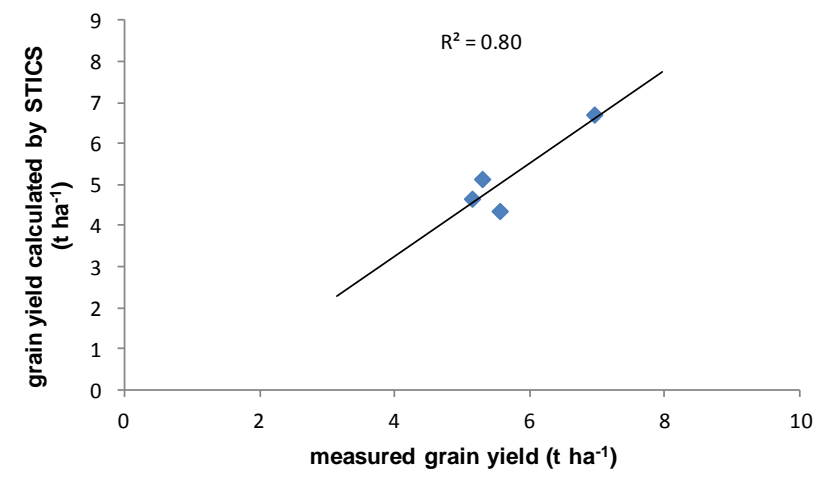

Figure 6. Comparison of simulated and measured grain yield using validation data set

\subsubsection{Soil water content}

Figure 7 shows the comparison of the simulated and observed soil water content (SWC). We notice that the performance of STICS is satisfactory as the coefficient of determination is greater than 0.5 [62]; [63]. Comparative analyses of the observed and simulated SWC had a ME of 0.7, and MB of 0.02. This highlights a comparatively good fit between the observed and the simulated results, as [28] and [29] consider that simulation is acceptable if ME is greater than 0.5 and $\mathrm{MB}$ is lower than 0.1 . The good agreement between measured and 
simulated is also reflected in the RMSE value which represents $26 \%$ of the average SWC observed value [64]. These results show the ability of STICS to simulate SWC under various irrigation regimes.

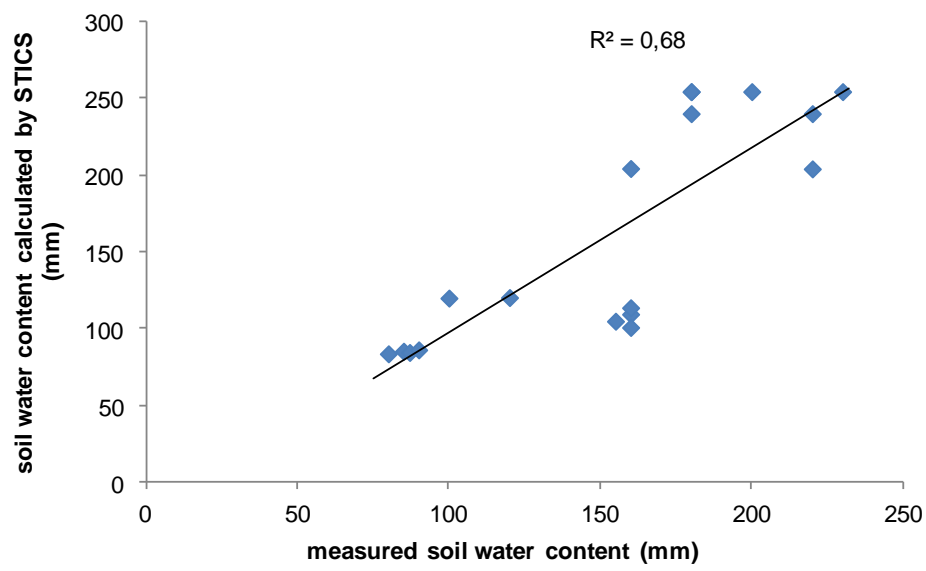

Figure 7. Comparison of simulated and measured soil water content

These results prove the ability of STICS to study the effect of location, soil type and irrigation management on crop production under rainfed and irrigated agriculture. The aptitude of the STICS model in predicting yield and biomass, in a Mediterranean environment, is therefore acceptable

\subsection{Model application}

3.3.1. Grain yield

Grain yield was increased by increased irrigation amounts for the three soils. Figure 8 indicates that I50 and I25 resulted, in higher grain yield as compared to farmers irrigation practice. Increased yield with increased irrigation amounts shows a positive effect of irrigation on grain yield. These results corroborate the findings of several studies [65] [66] [67] and [68]. Higher grain yield obtained in I50 and I25 could be attributed to higher grain weight with increasing irrigation [69] [70]. Compared to treatment (I25), treatment (I50) exhibited between 10 and $16 \%$ grain yield decrease.

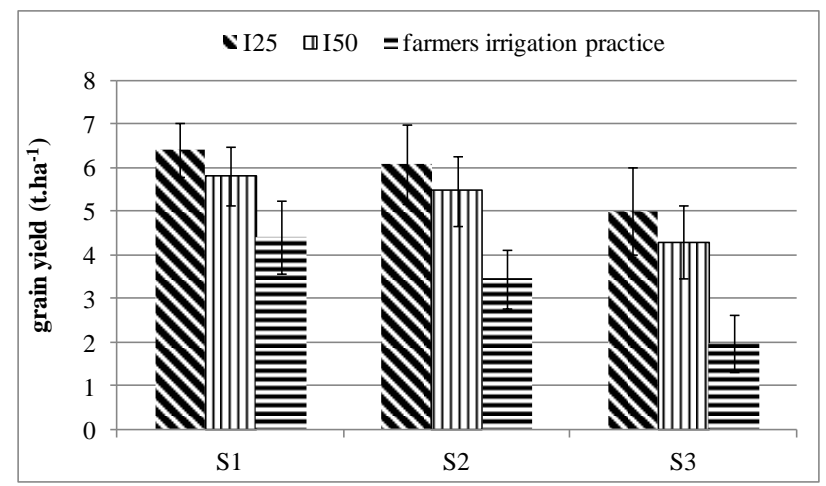

Figure 8. Average and standard deviations values of grain yield, simulated by the STICS model, in the three soils as a function of water management

Low grain yield obtained for farmers irrigation practices could be explained by an intensive water stress during grain filling period. This contributes highly in reducing grain weight [67].

The highest values of grain yield were obtained in soil having high TAW. In I50 and I25 scenarios, highest grain yield, averaging respectively 5.8 and $6.4 \mathrm{tha}^{-1}$ was obtained in S1, while S3 had the lowest yield value. In S3, the reduction in grain yield may be a consequence of a crop water stress occurring during the reproductive stage of wheat, much more frequent in soil having low total available water. It seems that soil with high TAW creates more suitable conditions in the root zone area for plant production. 


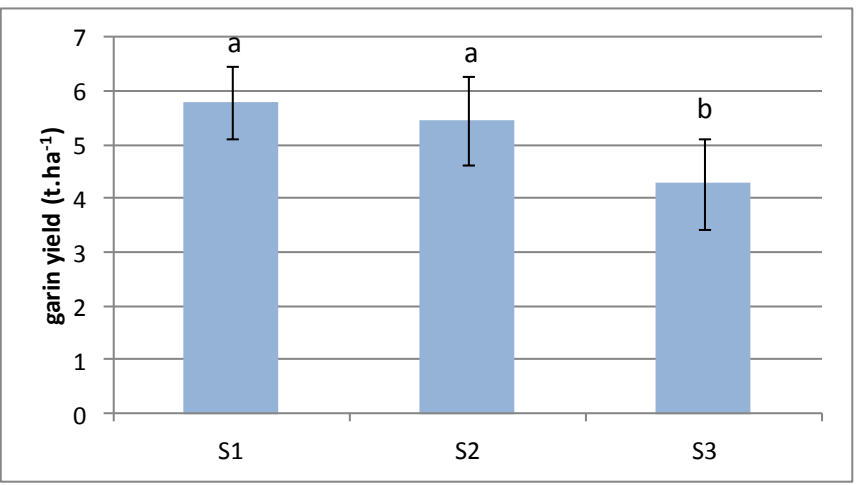

Figure 9. Average (1986-2006 period) and standard deviations values of grain yield, simulated by the STICS model, in the three soils for (I50) irrigation scenario

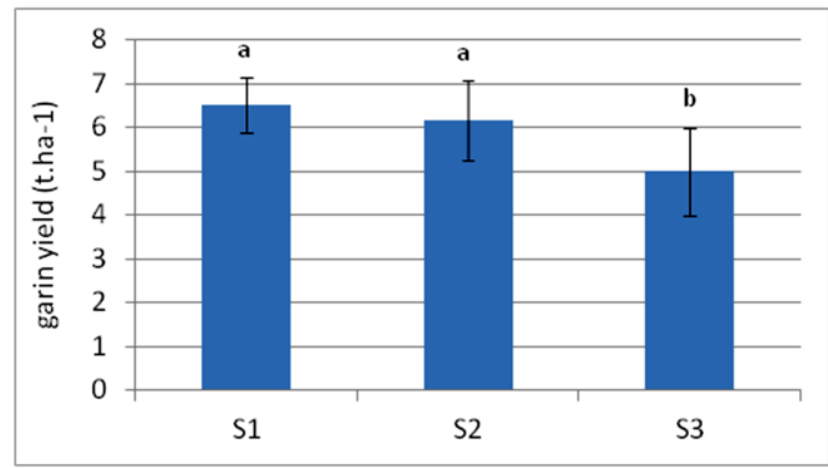

Figure 10. Average (1986-2006 period) and standard deviations values of grain yield simulated by the STICS model, in the three soils for (I25) irrigation scenario

For I25 (figure 10), wheat conducted in S2 and S3 produced in average respectively 6 and 27\% lower grain yield with regard to S1. While for I50 (fig.11), S2 and S3 resulted respectively in almost 5 and $21 \%$ reduction in grain yield respect to $\mathrm{S} 1$.

No statistical difference was found in grain yield between S1 and S2 for the two irrigation scenarios. This could be explained by the fact that water stress conditions, during critical stage of wheat, affected yield similarly in plants conducted in S1 and S2

\subsubsection{Dry matter yield}

Figure 11 indicates that I50 and I25 resulted, in higher total dry mater at harvest as compared to Farmers irrigation practice. In the two irrigation scenarios, dry matter at harvest was increased, depending on the soil type, from $43 \%$ to $150 \%$ respect to farmers irrigation practices. This is in agreement with the results reported by [71] who indicated that biological yield was increased as irrigation increased.

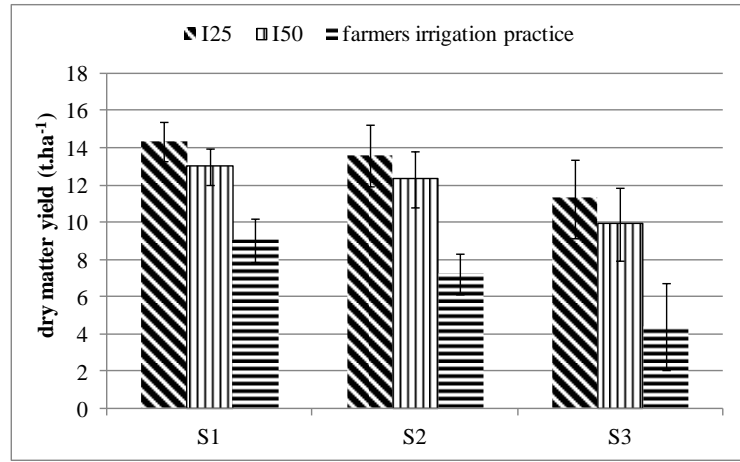

Figure 11. Average and standard deviations values of aerial dry matter at harvest, simulated by the STICS model, in the three soils as a function of water management

Generally, lowest values of dry matter at harvest were recorded in the soil with a low TAW value. Moreover, highest difference in above ground biomass, resulting from the two irrigation scenarios respect to the farmers 
irrigation practices, was obtained in soil with lowest TAW. Indeed, in S3, the biological yield increased by 58\% on average, moving from farmer's irrigation practice to I25 treatment. While in S1 having highest TAW, the dry matter values increased by $150 \%$ on average moving from farmer's irrigation practice to I25 treatment..

For I25 (figure 13), highest values were obtained in soil having high TAW with 14.32 t.ha $^{-1}$. While, for I50 (figure 12), average aerial dry matter, was $12.97,12.28$ and 9.89 t.ha $^{-1}$ respectively in S1, S2 and S3.

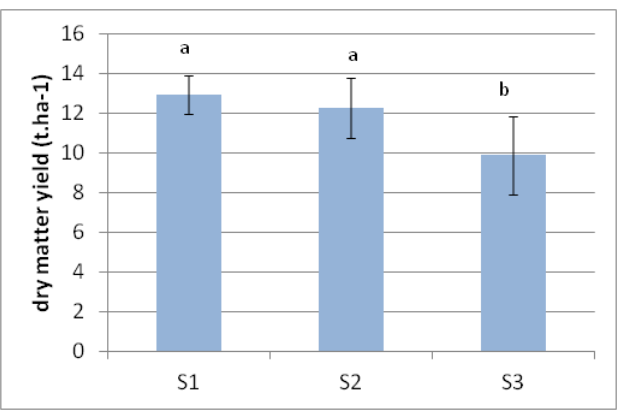

Figure 12. Average (1986-2006 period) and standard deviations values of dry matter yield simulated by the STICS model for I50 scenario in the three soils

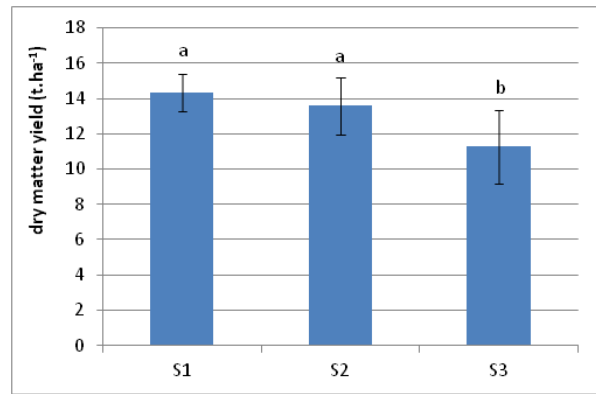

Figure 13. Average (1986-2006 period) and standard deviation values of dry matter yield simulated by the STICS model for $\mathbf{2 5}$ irrigation scenario in the three soils

\subsubsection{Water use efficiency at biomass basis}

Figure 14 shows the effects of different irrigation treatments on crop water use efficiency in the three soils. It indicates that I50 and I25 resulted, in higher $\mathrm{WUE}_{\text {bio }}$ as compared to farmers' irrigation practice.

In $\mathrm{S} 1$, the $\mathrm{WUE}_{\mathrm{bio}}$ values increased by $17 \%$ (from 4.23 to $4.97 \mathrm{~kg} \cdot \mathrm{m}^{-3}$ ) on average, moving from farmer's irrigation practice to I25. WUE values were therefore higher than those observed in the other two soils. While in S3 having lowest TAW, the $\mathrm{WUE}_{\text {bio }}$ values increased by $32 \%$ on average moving from to farmer's irrigation practice to I25. WUE ${ }_{\text {bio }}$ values were therefore lower than those observed in the other two soils. This confirms the findings of [72] showing that water use efficiency increased with increasing water supply. In I50 and I25 scenarios, highest $\mathrm{WUE}_{\text {bio }}$, averaging respectively 4.76 and $4.97 \mathrm{~kg} \mathrm{~m}^{-3}$ was obtained in S1, while S3 had the lowest $\mathrm{WUE}_{\text {bio }}$ value. For I25 (figure 15), wheat conducted in S2 and S3 produced in average respectively 3 and $17 \%$ lower $\mathrm{WUE}_{\text {bio }}$ with regard to S1. While for I50 (figure 16), S2 and S3 resulted respectively in almost 6 and $13 \%$ reduction in $\mathrm{WUE}_{\text {bio }}$ respect to $\mathrm{S} 1$. No statistical difference was found in grain yield between $\mathrm{S} 1$ and $\mathrm{S} 2$ for the two irrigation scenarios.

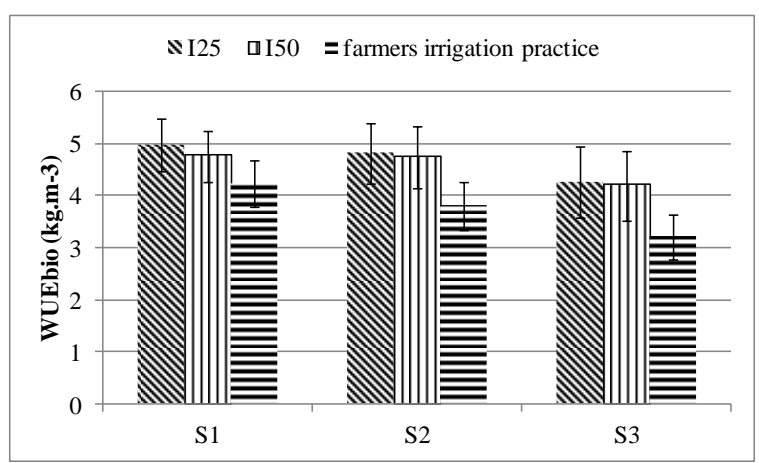

Figure 14. Average and standard deviations values of $\mathrm{WUE}_{\text {bio }}$ simulated by STICS in the three soils as a function of water management 


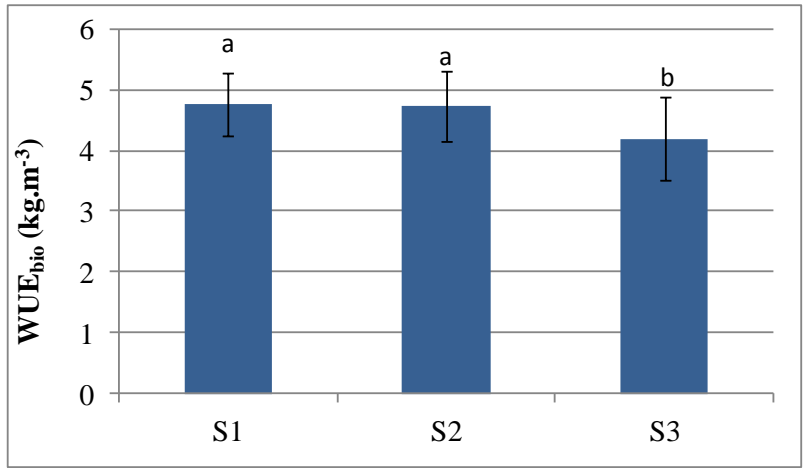

Figure 15. Average values of $\mathrm{WUE}_{\text {bio }}$ simulated by STICS in the three soils for I25 irrigation scenario

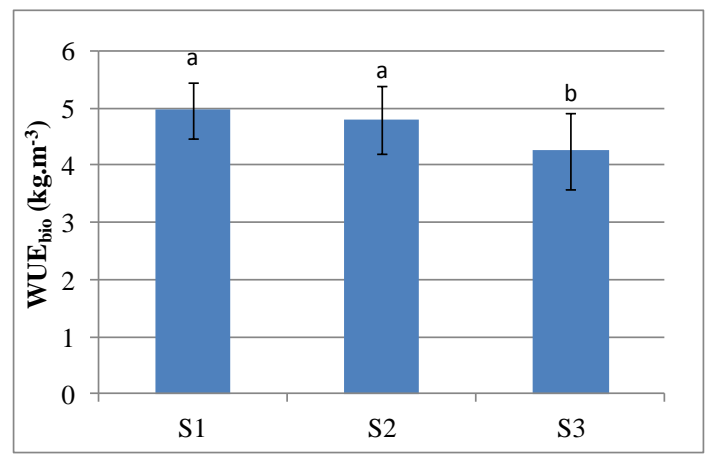

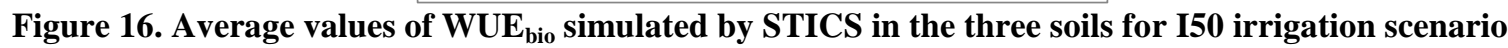

\subsubsection{Water use efficiency at grain basis}

Figure 17 show the effects of irrigation management on crop water use efficiency as a function of irrigation management. As noticed for $\mathrm{WUE}_{\text {bio }}$, highest values of $\mathrm{WUE}_{\mathrm{g}}$ were registred in I50 and I25. Average WUE $_{\mathrm{g}}$, for I25, was 2.26, 2.18 and $1.93 \mathrm{~kg} \cdot \mathrm{m}^{-3}$ respectively in S1, S2 and S3 (figure 19). These values are higher than average water use efficiency observed for the whole Mediterranean region [73]. Moreover when comparing effects of irrigation on crop water use efficiency, it should be kept in mind that the generic term "irrigated crops" can include, in reality, extremely different situations of plant water supply [50].

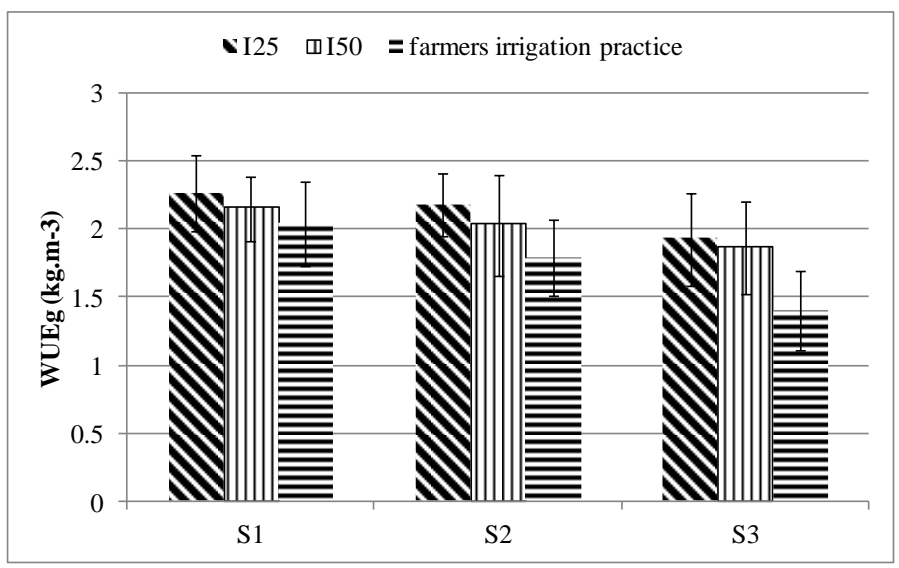

Figure 17. Average and standard deviations values of $\mathrm{WUE}_{\mathrm{g}}$ simulated by STICS in the three soils as a function of water management

Figure 18 showed that, in $\mathrm{I50}_{\mathrm{W}} \mathrm{WUE}_{\mathrm{g}}$ varied according to soil type. Highest $\mathrm{WUE}_{\mathrm{g}}$ was obtained in soil having high TAW with $2.15 \mathrm{~kg} \cdot \mathrm{m}^{-3}$ and the lowest one was found in soil with lowest TAW with $1.86 \mathrm{~kg} \cdot \mathrm{m}^{-3}$. No statistical difference was found in grain yield between S1 and S2 for the two irrigation scenarios. This could be explained by the fact that water stress conditions, during critical stage of wheat, affected yield similarly in plants conducted in S1 and S2. 


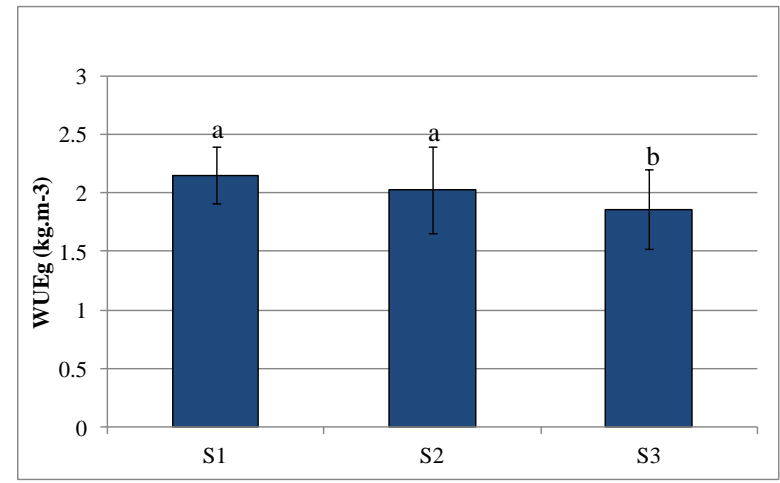

Figure 18. Average values of $\mathrm{WUE}_{\mathrm{g}}$ simulated by STICS in the three soils for I50 irrigation scenario

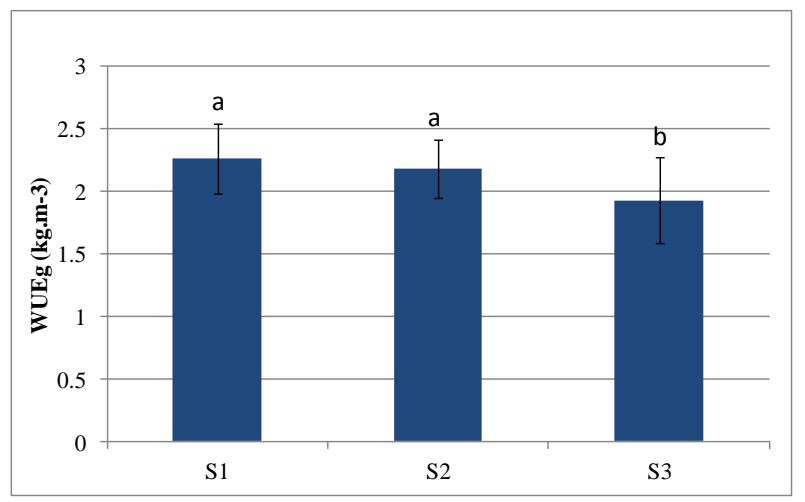

Figure 19. Average values of $W^{\prime} E_{g}$ simulated by STICS in the three soils for I25 irrigation scenario

Generally, lowest values of WUEg were recorded in the soil with a low TAW value. This is consistent with the findings of [12].

The reduction in WUEg values, may be a consequence of a more intense water deficit during critical stages, as suggested by [12]. In order to verify this hypothesis, the values of stomatal water stress indice (SWFAC) calculated by the STICS model, during vegetative and reproductive stages, as the ratio between actual transpiration and maximum transpiration were summarized in Table 9. It should be noticed that values of SWFAC range between 1 (no stress) and 0 (intense water stress).

Table 9. Average values of the stress index (SWFAC), simulated by the STICS model in the three soils as a function of water management

\begin{tabular}{|c|c|c|c|c|c|c|}
\hline & \multicolumn{3}{|c|}{ I25 } & \multicolumn{3}{|c|}{ I50 } \\
\hline & $\mathrm{S} 1$ & $\mathrm{~S} 2$ & S3 & S1 & S2 & $\mathrm{S} 3$ \\
\hline Vegetative stage & 1 & 1 & 0.99 & 0.99 & 0.98 & 0.96 \\
\hline Reproductive stage & 0.96 & 0.96 & 0.94 & 0.86 & 0.85 & 0.82 \\
\hline
\end{tabular}

In I25 and I50 irrigation scenarios, the water stress index shows close values in the three soils during the vegetative stage. Contrarily, this index is weaker during the reproductive stage.

\section{Conclusion}

In this study the impact of total available soil water in the root zone on the relation between water regime and WUE of a durum wheat cultivar was examined. After its validation, the STICS model was retained to simulate the variables required for the study. The results of STICS evaluation indicated that this model performed with satisfactory precision in terms of wheat yield and biomass. This study highlighted the existence of a consistency and a convergence in the results obtained with the grain yield and WUE indexes $\left(W^{2} E_{g}\right.$ and $W_{U} E_{b i o}$ ). It was determined that total available water in the root zone may significantly modulate the response of wheat water use efficiency, performed through the $\mathrm{WUE}_{\mathrm{g}}$ and $\mathrm{WUE}_{\mathrm{bio}}$ indexes, to the water regime. According to the research results, it was found that irrigation at sowing had a positive effect on crop water use efficiency. Moreover, highest difference in WUE was obtained in soil with highest TAW. Further studies should be conducted, taking into account the effects of various irrigation water schedules, in terms of crop water use efficiency, in soils having different properties. 


\section{References}

[1]. N. Sakiss, N. Ennabli, M.S. Slimani and H. Baccour, La pluviométrie en Tunisie a-t-elle changé depuis 2000 ans : Recherche de tendances et de cycles dans les séries pluviométriques (Institut National de la Météorologie (INM), Tunis, 1994).

[2]. N. Ben Mechlia. Perspectives de Valorisation de l'Eau d'Irrigation dans les Pays du Maghreb (Cahier Options méditerranéennes, Series B, $n^{\circ}$ 47. Water Management for Drought Mitigation in the Mediterranean (MAIB, Bari, Italy, 2004) $169-185$.

[3]. B. Ben Nouna, , N.Katerji and M.Mastrorilli, Using the CERES-Maize model in a semi-arid Mediterranean environment. Evaluation of model performance. Eur. J. Agron., 13, 2000, 309-322. http://dx.doi.org/10.1016/S1161-0301(00)00063-0

[4]. Y. Bozkurt, A. Yazar, B. Gencel and M.S. Sezen, Optimum lateral spacing for drip-irrigated corn in the Mediterranean Region of Turkey. Agr. Water Manage., 85, 2006, 113-120. http://dx.doi.org/10.1016/j.agwat.2006.03.019

[5]. C. De Fraiture and D. Wichelns, Looking ahead to 2050: scenarios of alternative investment approaches, In: D. Molden (Ed.), Water for Food, Water for Life: A Comprehensive Assessment of Water Management in Agriculture. (International Water Management Institute, Spikethscan and Colombo, London, 2007) 91-145.

[6]. M. Fanadzo, C. Chiduza, P.N.S. Mnkeni, I. Van der Stoep and J. Stevens, Crop production management practices as a cause for low water productivity at Zanyokwe irrigation scheme. Water SA 36(1), 2010, 27-36. http://dx.doi.org/10.4314/wsa.v36i1.50904

[7]. A.R. Sepaskhah, A. R. bazrafshan Jahromi and Z. shirmohammadi-Aliakbarkhani, Development and evaluation of a model for yield production of wheat, maize and sugarbeet under water and salt stresses. Biosystems engineering, 93(2), 2006, 139-152

[8]. A. Slama, M. Ben Salem, M. Ben Naceur, and E. Zid, Les céréales en Tunisie : production, effet de la sécheresse et mécanismes de résistance. science et changements planétaires. Sécheresse., 16 (3), 2005, 225-9.

[9]. S.J. Zwart and W.G.M. Bastiaanssen, Review of measured crop water pro-ductivity values for irrigated wheat, rice, cotton, and maize. Agric. Water Manag., 69, 2004, 115-133. http://dx.doi.org/10.1016/j.agwat.2004.04.007

[10]. FAO, Unlocking the water potential of agriculture. FAO Corporate Document Repository. (FAO, Rome, Italy, 2003)

[11]. T. Oweis, Supplemental Irrigation. A Highly Efficient Water Use Practice ( ICARDA Editions, ICARDA, 1997)

[12]. N. Katerji, M. Mastrorilli and H. Cherni, Effects of corn deficit irrigation and soil properties on water use efficiency. A25-years spike analysis of a Mediterranean environment using the STICS model. Europ. J. Agronomy, 28, 2010 , 493-507. http://dx.doi.org/10.1016/j.eja.2007.12.003

[13]. H. V. Varella, Inversion d'un modèle de culture pour estimer spatialement les propriétés des sols et améliorer la prédiction de variables agro-environnementales, doctoral diss, Academie d'Aix-Marseille, Université D'Avignon et des Pays de Vaucluse, Avignon, France, 2009.

[14]. Z. Saadati, N. Pirmoradian and M. Rezaei (2011). Calibration and evaluation of aquacrop model in rice growth simulation under different irrigation managements. ICID 21st International Congress on Irrigation and Drainage, 15-23 October 2011, Tehran, Iran

[15]. K.F. Ngetich, D. Raes, C.A. Shisanya,, J. Mugwe, M. Mucheru-Muna, D.N. Mugendi, and J. Diels, Calibration and validation of AquaCrop model for maize in sub-humid and semi-arid regions of central highlands of Kenya. Third RUFORUM Biennial Meeting 24 - 28 September 2012, Entebbe, Uganda

[16]. C.T. De Wit and F.W.T. Penning de Vries, Predictive models in agricultural production (Philosophical Transactions of the Royal Society of London, Series B 310, 1985)

[17]. R.L.McCown, Z. Hochman and P.S. Carberry, Probing the enigma of the decision support system for farmers. Agricultural Systems, 74 (1), 2002, 1-220 (Special Issue). http://dx.doi.org/10.1016/S0308-521X(02)00026-4

[18]. L.R. Ahuja, L.Ma and T.A. Howell, Agricultural System Models in Field Research and Technology Transfer (Lewis Publishers, Boca Raton, FL, 2002)

[19]. M. Bindi and F. Maselli, Extension of crop model outputs over the land surface by the application of statistical and neural network techniques to topographical and satellite data. Climate Research, 16, 2001, 237-246. http://dx.doi.org/10.3354/cr016237

[20]. N. Brisson, B. Mary, D. Ripoche, M.H.Jeuffroy, F. Ruget, B. Nicoullaud, P. Gate, F. Devienne-Barret, R. Antonioletti, C. Durr, G. Richard, N. Beaudoin, S. Recous, X. Tayot, D. Plenet, P. Cellier, J.M. Machet and R. Delecolle, STICS: a generic model for the simulation of crops and their water and nitrogen balances. Theory and parametrization applied to wheat and corn. Agronomy 18, 1998, 311-346. http://dx.doi.org/10.1051/agro:19980501

[21]. N. Brisson, F. Huard, A.I. Graux, C. Lebas, P. Debaeke, G. Lemaire and B. Itier, Evaluation régionale de l'impact de la sécheresse agricole à l'aide d'un modèle biophysique (INRA, Unité Agro-Clim. Avignon, 2006)

[22]. R.G. Allen, L.S. Pereira, D. Raes and M. Smith, Crop evapotranspiration: guide-lines for computing crop water requirements, Irrigation and Drainage Paper No. 56 (FAO, Rome, 1998).

[23]. T. Hazmoune (2000). Durum wheat improvement in the Mediterranean region: New challenges. In C. Royo (ed.), M. Nachit (ed.), N. Di Fonzo (ed.), J.L. Araus (ed.), Options Méditerranéennes : Série A. Séminaires Méditerranéens; n. 40 (MAIB, Bari, Italy, 2000) 291-294

[24]. N. Brisson, , C. Gary, E. Justes, R. Roche, B. Mary, D. Ripoche, D. Zimmer, J. Sierra, P. Bertuzzui, P. Burger, F. Bussiere, Y.M. Cabidoche, P. Cellier, P. Debaeke, J.P. Gaudillere, F. Maraux, B. Seguin and H. Sinoquet, An overview of the crop model STICS. Eur. J. Agron., 18, 2003, 309-332. http://dx.doi.org/10.1016/S1161-0301(02)00110-7

[25]. C. Lauvernet, L. Hasco, F.X. Le Dimet and F. Baret, Using Automatic Differentiation to Study the Sensitivity of a Crop Model. Proceedings of the AD conference, Fort Collins (CO), USA, 2012

[26]. F. Ruget, N. Brisson, R. Delécolle and R. Faivre, Sensitivity analysis of a crop simulation model, STICS, in order to choose the main parameters to be estimated. Agronomy, 22, 2002, 133-158. http://dx.doi.org/10.1051/agro:2002009

[27]. V. Houles, B. Mary, M. Guerif, D. Makowski and E.Juste, Evaluation of the crop model STICS to recommend nitrogen fertilization rates according to agro-environmental criteria. Agronomie, 24, 2004, 1-9. http://dx.doi.org/10.1051/agro:2004036

[28]. N. Beaudoin, M. Launay, E.Sauboua, G. Ponsardin and B.Mary, Evaluation of the soil crop model STICS over 8 years against the "on farm" database of Bruyeres catchment. European Journal of Agronomy, 29, 2008, 46-57. http://dx.doi.org/10.1016/j.eja.2008.03.001

[29]. N. Brisson, F. Ruget, P. Gate, J. Lorgeou, B. Nicoullaud, X. Tayot, D. Plenet, M.H. Jeuffroy, A. Bouthier, D. Ripoche, B. Mary and E. Justes, STICS a generic model for simulating crops and their water and nitrogen balances. II. Model validation for wheat and maize. Agronomy, 22, 2002, 69-92. http://dx.doi.org/10.1051/agro:2001005

[30]. A.I. Heuer and M.C. Casper, Studying Parameter Sensitivity and Behaviour of the Crop Model STICS. The Open Hydrology Journal, 5, 2011, 58-68. http://dx.doi.org/10.2174/1874378101105010058

[31]. C.T. De Wit, Simulation of assimilation, respiration and transpiration of crops. Simulation monographs (Centre for Agricultural Publishing and Documentation, Wageningen. The Netherlands, 1978)

[32]. N. Huth and D. Holzworth, Common Sense in Model Testing, Proceedings of MODSIM 2005, International Congress on Modelling and Simulation, Melbourne, Australia, December 2005.

[33]. K. Metselaar, Auditing predictive models: a case study in crop growth, doctoral diss, Wageningen Agricultural University, Wageningen, 1999.

[34]. A.J. Jakeman, R.A. Letcher and J.P. Norton, Ten iterative steps in development and evaluation of environmental models. Environmental Modelling \& Software, 21(5), 2006, 602-614. http://dx.doi.org/10.1016/j.envsoft.2006.01.004

[35]. S.P. Prisley and M.J. Mortimer, A synthesis of literature on evaluation of models for policy applications, with implications for forest carbon accounting. Forest Ecology and Management, 198, 2004, 89-103. http://dx.doi.org/10.1016/j.foreco.2004.03.038

[36]. D. Wallach, S. Buis, P. Lecharpentier, J. Bourges, P. Clastre, M. Launay, J.E. Bergez, M. Guerif, J. Soudais and E. Justes, A package o f parameter estimation meth ods and impleme ntation for the STICS crop-soil mode 1. Environmental Modelling \& Software, 26, 2011, 386394. http://dx.doi.org/10.1016/j.envsoft.2010.09.004 
[37]. K. Latiri-Souki, Analysis of the effects of water and nitrogen supply on the yield and growth of durum wheat unser semi-arid conditions in Tunisia, doctoral diss, University of Reading, London, U K, 1994

[38]. M. Rezgui, Itinéraire technique et rendement de trois variétés de blé dur sous régime d'irrigation d'appoint. Master's thesis. University of Tunis Carthage, National Agronomic Institute of Tunisia. Tunis, Tunisia, 1998

[39]. M. Haffani, Modélisation agrométéorologique de la croissance du blé, Master's thesis. University of Tunis Carthage, National Agronomic Institute of Tunisia, Tunis, Tunisia, 1996

[40]. J.A.Colton and K.M. Bower. Some Misconceptions about $R^{2}$, International Society of Six Sigma Professionals, extraordinary Sense, 3 (2), 2002, 20-22

[41]. E. Lichtfouse, M.Hamelin and M. Navarrete, Sustainable Agriculture: Volume 2, Springer 2011, ISBN 9789400703933 ,

[42]. D. G. Mayer and D. G. Butler, Statistical validation. Ecol. Model., 68, 1993, 21-32. http://dx.doi.org/10.1016/0304-3800(93)90105-2

[43]. J. E. Nash and J. V. Sutcliffe, River flow forecasting through con-ceptual models, Part I - A discussion of principles, J. Hydrol., 10, 1970, 282-290. http://dx.doi.org/10.1016/0022-1694(70)90255-6

[44]. D.J. Greenwood, J.J. Neeteson and A. Draycott, Response of potatoes to N-fertilizer: Dynamic model. Plant Soil, 85, $1985,185-203$. http://dx.doi.org/10.1007/BF02139623

[45]. K. Loague and R.E. Green, Statistical and graphical methods for evaluating solute transport models: Overview and application. J. Contam. Hydrol., 7, 1991, 51-73. http://dx.doi.org/10.1016/0169-7722(91)90038-3

[46]. G. Bellocchi, M. Rivington, M. Donatelli and K. Matthews, Validation of biophysical models: issues and methodologies. A review. Agron. Sustain. Dev, 2009. http://dx.doi.org/10.1051/agro/2009001

[47]. A. Hamdy, Water use efficiency in irrigated agriculture: an analytical review, (Cahier Options méditerranéennes, Series B, $n^{\circ} 57$. Water Use Efficiency and Water Productivity. 2005) $9-19$.

[48]. FAO. La petite irrigation dans les zones arides (FAO, Rome, 1997)

[49]. L. Perreira, Relating water productivity and crop evapotranspiration, (Cahier Options méditerranéennes, Series B, $n^{\circ} 57$. Water Use Efficiency and Water Productivity, 2005) $31-50$

[50]. N. Katerji, M. Mastrorilli and G. Rana, Water use efficiency of crops cultivated in the Mediterranean region: Review and analysis. Europ. $J$. Agronomy 28 (32), 2010, 177-185.

[51]. N. Katerji and G. Rana, Modelling evapotranspiration of six irrigated crops under Mediterranean climate conditions. Agric. Forest Meteorol. 138, 2006, 142-155. http://dx.doi.org/10.1016/j.agrformet.2006.04.006

[52]. D.X. Chen and M.B. Coughenour, Photosynthesis, transpiration, and pri-mary productivity: Scaling up from leaves to canopies and regions using process models and remotely sensed data. Global Biogeochem. Cycles 18, 2004, 1-15. http://dx.doi.org/10.1029/2002GB001979

[53]. R.A. Feddes, Crop water use and dry matter production: state of the art. Proc.Conf. on Les besoins en eau des cultures, Paris, 1984, 221234.

[54]. T. Hsiao, P. Steduto and E. Fereres, A systematic and quantitative approach to improve water use efficiency in agriculture. Irrig. Sci., 25, 2007, 209-231. http://dx.doi.org/10.1007/s00271-007-0063-2

[55]. P.E. Rijtema and G. Endrodi, Calculation of production of potatoes. Neth.J. Agric. Sci., 18 (1), 1970, 26-36.

[56]. P.J. Slabbers, V. Sorbello Herrendorf and M. Stepper, Evaluation of simpli-fied water-crop-yield models. Agric. Water Manag. 2, 1979, 95129. http://dx.doi.org/10.1016/0378-3774(79)90026-X

[57]. J.T. Ritchie, Efficient water use in crop production: discussion on the generality of relations between biomass production and evapotranspiration. In: Taylor, H.M., Jordan, W.R., Sinclair, T.R. (Eds.), Limitations to Efficient Water Use in Crop Production. (Madison, WI, 1983) 29-43.

[58]. C.B. Tanner and T.R. Sinclair, Efficient water use in crop production: research or research. In: Taylor, H.M., Jordan, W.R., Sinclair, T.R. (Eds.), (Limitations to Efficient Water Use in Crop Production, 1983) 1-27

[59]. L.S. Pereira, T. Oweis, A. Zairi, Irrigation management under water scarcity. Agric. Water Manag., 57, $2002,175-206$.

[60]. N.C. Turner, Agronomic options for improving rainfall-use efficiency of crops in dryland farming systems. J. Exp. Bot., 55, 2004, 24132425. http://dx.doi.org/10.1093/jxb/erh154

[61]. N. Katerji, J.W. van Hoorn, A. Hamdy, M. Mastrorilli and T. Oweis, Salt tolerance analysis of chickpea, faba bean and durum wheat varieties. I. Chickpea and faba bean. Agric. Water Manag. 72, 2005, 177-194. http://dx.doi.org/10.1016/j.agwat.2004.09.014

[62]. C. Santhi, , J. G. Arnold, J. R. Williams, W. A. Dugas, R. Srinivasan, and L. M. Hauck. Validation of the SWAT model on a large river basin with point and nonpoint sources. J. American Water Resources Assoc. 37(5), 2001, 1169-1188

[63]. M. W. Van Liew, J. G. Arnold, and J. D. Garbrecht, Hydro-logic simulation on agricultural watersheds: Choosing between two models. Trans. ASAE 46(6), 2003, 1539-1551.

[64]. P.D. Jamieson, M.A. Semenov, I.R. Brooking and G.S. Francis, Sirius: a mechanistic model of wheat response to environmental variation. European Journal of Agronomy 8, 1998, 161-179.

[65]. K. Shamsi, S. Kobraee and B. Rasekhi, Bread wheat production under drought stress conditions. Annals of Biological Research, 2 (2), 2011, 372-377

[66]. M.E. Ghobadi, H. Felehkari, G.R. Mohammadi and S.J. Honarmand, The effects of supplemental irrigation and N-applications on yield and yield component in two wheat cultivars in Kermanshah condition. Annals of Biological Research, 3, 2012, $2127-2133$.

[67]. Z.V.I. Hochman, Effect of water stress with phasic development on yield of wheat grown in a semi-arid environment. Field Crops Res., 5. 198255-67. http://dx.doi.org/10.1016/0378-4290(82)90006-5

[68]. M. H. Romena and A Najaphy, Physiological characteristics and grain yield of wheat under irrigated and rain-fed conditions.. Annals of Biological Research. 3 (7), 2012, 178-3182.

[69]. N. Sarwar, M.Maqsood, K. Mubeen, M.Shehzad, M.S. Bhullar, K. Qamar, and N. Akbar, Influence of sowing date and irrigation levels on growth and grain yield of wheat. Pak. J. Agri. Sci. 39(1), 2010, 22-24.

[70]. A. Wajid, A. Hussain, M. Maqsood, A. Ahmad and M. Awais, Effect of different levels of irrigation on yield and yield components of wheat cultivars. Pak. J. Agri. Sci., 47(3), 2002, 371-374.

[71]. T. Kobata, J.A. Palta and Turner, N.C. Rate of development of post anthesis water deficits and grain filling of spring wheat. Crop Sci., 32, $1992,1238-1242$.

[72]. W. Li and Z. Li, Irrigation and fertilizer effects on water use and yield of spring wheat in semi-arid regions. Agric. Water Manage., 67, 2004, $35-46$.

[73]. V.O. Sadras and J.F.Angus, Benchmarking water use efficiency of rainfed wheat in dry environments. Aust. J. Agric. Res., 57, 2006, 847856. http://dx.doi.org/10.1071/AR05359 